\title{
ICТОРІОГРАФІЧНІ РОЗВІДКИ
}

\author{
Дячок Олег \\ (Дніпропетровсък)
}

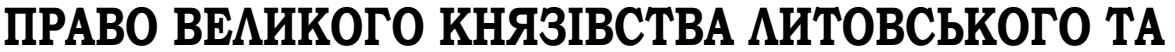 УКРАЇНСЬКИХ ЗЕМЕАЬ У ЙОГО СКААДІ НА СТОРІНКАХ УКРАЇНСЬКИХ ЮРИДИЧНИХ ВИДАНЬ (1991-2007 pp.)}

Круглий стіл «Гісторыя вывучэння Вялікага княства Літоўскага ў Х1991-2003 гг.», що відбувся 16-18 травня 2003 р. в м. Гродно, та видання його матеріалів, безумовно, стали значною науковою подією, що дозволила ученим різних країн, які займаються вивченням історії ВКЛ, краще дізнатися про напрацювання та досягнення своїх колег. Однак, у процесі роботи круглого столу не могли бути розглянуті всі аспекти історіографії історії ВКЛ. Зокрема, українські дослідники практично не торкалися публікацій 3 історії права та державних установ ВКЛ, здійснених вітчизняними юристами (підтвердженням цьому $є$ питання литовського науковця Д. Вілімаса, задане під час дискусії, чи вивчає хто-небудь в Україні Статути ВКЛ $)$. В «Українській бібліографії Великого князівства Литовського 1990-2003 рр.» (укладачі: К. Кириченко, Д. Вирський) ${ }^{2}$, що містить 260 позицій, вказані тільки

Вялікае княства Літоўскае: гісторыя вывучэння ў 1991-2003 гг. = Grand Duchy of Lithuania: history of research, 1991-2003: матэрыялы міжнар. круглаго стала «Гісторыя вывучэння Вялікага княства Літоўскага ў 1991-2003 гг.», Гродна (16-18 мая 2003 г.) / рэдкал. С.Б. Каўн (адказ. рэд.) [і інш.]. - Мінск: Медисонт, 2006. - С. 539.

2 Українська бібліографія Великого князівства Литовського 1990-2003 pp. / Укладачі: К. Кириченко, Д. Вирський // Там само. - С. 514-536. 
сім статей, надрукованих в юридичних виданнях, та один автореферат на здобуття наукового ступеня кандидата юридичних наук, що не відображає дійсну картину. У 2005 р. на основі доповіді, виголошеної на гродненському круглому столі, К. Кириченко опублікувала статтю про основні тенденції в українській історіографії ВКЛ 1991-2003/4 pp. Але серед головних напрямків вивчення його історії праву відведено лише п'ять рядків, в яких згадуються роботи трьох авторів ${ }^{3}$.

У даному дослідженні аналізуються публікації українських істориків права, в яких їх автори так чи інакше торкалися аспектів функціонування державних і правових інститутів ВКЛ. Його предметом були обрані періодичні та неперіодичні (продовжувані) видання, що дає змогу зробити висновки про певні тенденції в даній науці, інтерес до тієї чи іншої тематики, роботу над дисертаціями тощо. Безперечно, автором статті аналізувались не всі публікації, а передусім, вміщенні у найавторитетніших i відповідно найпоширеніших юридичних виданнях.

У доповіді про основні тенденції української історіографії історії ВКЛ 1991-2003 pp., виголошеній на згадуваному круглому столі, К. Кириченко відзначила, що ще у XIX - на початку XX ст. у вітчизняній історіографії склався погляд на історію ВКЛ як на литовську добу в історії українських земель. Сучасна українська історіографія «тяжіє до регіоналістичних досліджень долі українських земель в т.зв. «Литовський період» (40-ві роки XIV - 1569)» ${ }^{4}$ Це характерно й для історико-правових студій. Українські історики права звертаються до права, органів влади та самоврядування ВКЛ передусім в контексті вивчення правових та державних інститутів, що мали місце на українських землях у його складі. Лише окремі публікації присвячені аналізові безпосередньо норм Литовських статутів. Прикладом є стаття О. Неліна про питання спадкового права за статутами 5 .

Разом 3 тим, саме статути ВКЛ привертають увагу дослідників у першу чергу. 3 одного боку, автори розглядають вплив права Київської Русі, передусім Руської Правди, на Литовські статути, порівнюють регулювання аналогічних інститутів цими актами. С. Кудін

3 Кириченко К. - Історія Великого князівства Литовського в українській історіографії 1991 - 2003/4: основні тенденції // Ruthenica. - 2005. - № 4. - С. 228.

4 Кириченко К. Історія Великого князівства Литовського в українській історіографії 1991 - 2003 рр.: основні тенденції // Вялікае княства Літоўскае: гісторыя вывучэння... - С. 484, 485.

5 Нелін O.I. До питання спадкового права за Статутами Великого князівства Литовського // Держава і право: Зб. наук. праць. Юрид. і політ. науки. - К., 2001. Вип. 13. - С. 48-52. 
проаналізував поняття кримінального штрафу, виявивши його спільні та відмінні риси у Руській Правді та Першому Литовському статуті. Порівнюючи три редакції статуту, він дійшов висновку, що у другій i третій редакціях кримінальний штраф втрачає домінуючу роль, законодавець все більше починає застосовувати фізичні покарання та позбавлення волі ${ }^{6}$. Інша стаття цього автора присвячена такому видові покарання як «поток і пограбування», зафіксованому у Руській Правді. Дослідник схиляється до думки, що під потоком слід розуміти вигнання, а під пограбуванням - конфіскацію. Учений відзначив, що це покарання вже не зустрічається після входження українських земель до ВКЛ, зокрема в уставній грамоті Київській землі 1507 р. та в уставі про маєтки державних зрадників 1509 р. Відсутнє воно і у Першому Литовському статуті: «Литовський статут теж не містить поєднання конфіскації з вигнанням: вона застосовується як самостійно... так i у поєднанні 3 втратою честі и смертною карою...» Поток же набув форми виволання (баниції), що відрізнялося від вигнання за Руською Правдою ${ }^{7}$.

3 іншого боку, українські автори аналізували вплив статутів ВКЛ на розвиток українського права, застосування їх положень. Праву ВКЛ в цілому та його впливові на становлення українського права присвячена компілятивна стаття Л. Коваленка. Її автор не тільки не звертався до правових пам'яток, а скидається, що й література, на основі якої вона написана, підібрана якось випадково - підручники, роботи відомих істориків та істориків права кінця XIX - першої половини XX ст.., дві різночасові статті. А на початку публікації навіть подибуємо вкрай некомпетентне твердження, що на ранньому етапі у ВКЛ поряд з Руською Правдою діяло великокнязівське законодавство, міжнародні договори, постанови сеймів і т.зв. Литовська метрика, хоча автор тут же зазначає, що це були книги великокнязівської канцелярії 8

О. Клименко звертається до окремих аспектів історіографії формування українського права та його взаємодії з іншими системами, навівши у своїй статті міркування щодо термінів «литовське право», «литовсько-українське право», «литовсько-білоруське право», «литовсько-руське право», «західно-руське право», які

6 Кудін C. Поняття кримінального штрафу за Руською Правдою та Литовським Статутом // Право України. - 2000. - №11. - С. 141-144.

7 Його ж. Поняття “поток і пограбування" у кримінальному праві України XI - першої половини XVII ст.: історично-правовий аналіз // Право України. 2003. - №6. - С. 132-135.

8 Коваленко Л. Право Великого князівства Литовського та його вплив на становлення українського права // Юридична Україна. - 2004. - № 2 (14). - С. 91-95. 
висловив С. Борисенок ще наприкінці 20-х років ХХ ст.. Однак бібліографія дослідження надто бідна. Жодного власного історикопорівняльного аналізу автором не здійснено. А висновок, що «система українського права, взявши свої витоки 3 давньоруського права та переживши імплементацію 3 литовським правом, трансформувалася у власну, відмінну від інших, систему права» ${ }^{9}$ не випливає 3 усього попереднього тексту.

I. Грозовський, досліджуючи «козацьке право» (сукупність правових звичаїв, які склалися в Запорозькій Січі) звернув увагу, що в процесі свого розвитку воно взаємодіяло 3 правовими системами сусідніх народів і держав. Зокрема, він вказує на тотожні покарання за крадіжку, притаманні праву запорожців та Литовським статутам, показуючи це на прикладі статуту 1588 р. (артикул 7 розділу XIV). Подібність автор пояснив трьома причинами: 1) юридичним джерелом Литовських статутів і «козацького права» були норми давньоруського права; 2) «основну масу козацького війська складали вихідці 3 українських земель, правосвідомість яких змалку складалася під впливом литовсько-польського законодавства»; 3) «сучасники, спогади яких $є$ одним із джерел для вивчення козацького права, при характеристиці звичаєвого права запорожців могли використовувати звичні формули законодавства, яке існувало в той час, зокрема, Литовських статутів» ${ }^{10}$. Проте останнє твердження не розкриває причини аналогічних правових норм - воно почасти розкриває особливості сприйняття звичаєвих норм запорожців представниками інших верств населення. I, безперечно, це слід враховувати, працюючи з наративними джерелами, аби уникати екстраполяції на «козацьке право» нетипових для нього елементів. Деякі висновки І. Грозовського знаходять аналогії в дослідженнях інших авторів. Так, на думку українського історика В. Щербака, на генезу козацького права, безумовно, впливало литовське законодавство: «Адже більшість прибулих на Запорожжя раніше проживали на землях, де домінувало литовське право, що не могло не позначитися на правових уявленнях січової громади». Однак останній посилається на положення 1, 10 i 12 артикулів розділу ХІІІ статуту 1529 р., в яких йдеться про покарання на смерть за вчинення кримінального злочину i які застосовувались i в практиці запорозького суду. Історик наголошує, що це не випадково, адже в основу законодавства ВКЛ були покладені й норми українського звичаєвого права ${ }^{11}$.

9 Клименко О. Формування українського права та його взаємодія з іншими правовими системами // Право України. - 2001. - № 9. - С. 86-88.

10 Грозовський I. Феномен козацького права // Вісник Академії правових наук України. - 1997. - №3 (10). - С. 124-125. 
Один з авторів звернув увагу на великокнязівські листи й артикули Першого та Другого Литовських статутів, якими регламентувалися торгівля та митна справа на Київщин ${ }^{12}$, хоча положення статутів однаковою мірою поширювалися на всю територію ВКЛ. А твердження, що Перший статут охоплював основні положення митного права $\epsilon$ явно натягнутим - навіть сьогодні не всі правники погоджуються 3 виділенням митного права як підгалузі адміністративного, тоді як в названому нормативно-правовому акті була лише одна «митна» стаття. Посилання на Перший статут є і в статті В.К. Ковальського про становлення митної справи на території Миколаївської області, однак інформацію про встановлення тут митниць великими князями литовськими автор запозичив з інших досліджень. Матеріал статті повністю ввійшов до монографії В.К. Ковальського, виданої на основі захищеної кандидатської дисертації. У монографії він доповнений розкриттям змісту статей, що регулювали митні відносини, вміщених у Другому і Третьому статутах ${ }^{13}$.

Д. Любченко, аналізуючи види злочинів у кримінальному праві Гетьманщини, задається питанням, «якою мірою норми Литовського статуту $1588 \mathrm{p}$. та звичаєвого права вплинули на гетьманські універсали другої половини XVII - першої чверті XVIII ст.» На його думку, в повсякденній практиці судді виходили із здорового глузду, застосовуючи ті положення статуту, що не суперечили політикоправовим реаліям (здача фортеці, фальшування монети, посягання у будь-якій формі на державну власність, листування з ворогом, підробка урядових паперів, печаток тощо). Відзначаючи чинність Третього Литовського статуту на території Гетьманщини, автор припускає, що судді могли кваліфікувати хабарництво, підробку документів та деякі інші службові злочин, виходячи з тих їх характерних ознак, які містилися

${ }^{11}$ Щербак В. Витоки та становлення козацького права // Україна в ЦентральноСхідній Європі. - К., 2000. - Вип. 1. - С. 121.

12 Павлов $A$. Литовський статут та Магдебурзьке право: їх роль у розвитку торгівлі і митної справи на Київщині (XV-XVII ст.) // Право України. - 2003. № 10. - С. 146-148.

${ }^{13}$ Ковальский В.К. Становление таможенного дела на территории Николаевской области (с древнейших времён до образования города Николаева) // Митна справа. - 2003. - №6. - С. 89-91; Його ж. Становлення та розвиток митної справи на Півдні України з давніх часів до 1917 року (на матеріалах Миколаївської митниці). Автореф. ... канд. юр. наук. 12.00.01 - теорія та історія держави і права; історія політичних і правових учень. - Одеса, 2004 // http://www.law1.boom.ru/diser/01/k2919-04.htm; Його ж. Становлення та розвиток митної справи на Півдні України з давніх часів до 1917 року (на прикладі Миколаївської митниці). - Одеса: Юридична література, 2006. C. 29-31. 
у нормах цього кодексу. Дослідник доходить висновку, що норми Литовського статуту 1588 р. зробили певний вплив на зміст гетьманських універсалів. Позитивним є те, що ця невелика за обсягом стаття написана на основі аналізу універсалів, автор висловив власні міркування ${ }^{14}$. Однак публікація ще більше б виграла, якби чітко були виявлені норми, запозичені зі статуту без змін, з певними змінами тощо.

Слід виділити грунтовне історіографічне дослідження O.M. Коросташова, присвячене дослідженню українськими та російськими вченими застосування норм Литовського статуту у Полтавській i Чернігівській губерніях після скасування місцевого права, з 1842 р. Його автор проаналізував особливості поглядів на дане питання науковців середини XIX-XX ст., а також виділив чотири періоди у його вивченні, охарактеризувавши кожен 3 них ${ }^{15}$. Широко історіографія представлена й у кандидатській дисертації O.M. Коросташова. У авторефераті він також стверджує наступне: «Враховуючи те, що Литовський статут (основне джерело місцевого права на Лівобережжі) був кодексом феодального права, на думку автора, економічний та соціальний розвиток України призводив до необхідності перегляду хоча б його окремих положень. Разом 3 тим, значна кількість норм статуту відповідала соціально-економічним відносинам, що існували в Україні» ${ }^{16}$.

Окремі статті присвячені правовому регулюванню окремих відносин впродовж тривалого часу, зокрема й Литовськими статутами, в період входження українських земель до ВКЛ. Г. Богомаз, О. Вовк та О. Кучинська, аналізуючи законодавство про потерпілих, звернулися до статуту 1529 р. Автори відзначили, що він передбачав відшкодування потерпілим шкоди залежно від їх соціального становища ${ }^{17}$. Особливо слід відзначити статтю Є. Шаломєєва про розвиток поняття злочину в кримінальному праві України X - кінця XVII ст. Він проаналізував

14 Любченко Д. Види злочинів у кримінальному праві Гетьманщини за універсалами другої половини XVII - першої чверті XVIII ст. // Право України. 2007. - № 6. - С. 138-140.

15 Коросташов O.M. Застосування норм Литовського Статуту у Полтавській і Чернігівській губерніях після скасування місцевого права (історіографія питання) // Держава і право. - К, 2002. - Вип. 16. - С. 41-46.

${ }^{16}$ Йогож. Особливостіправового регулювання цивільних відносину Полтавській і Чернігівській губерніях (перша половина ХІХ століття). Автореф. ... канд. юр. наук. 12.00.01 - теорія та історія держави і права; історія політичних і правових учень. - К., $2001 / /$ http://www.law1.boom.ru/diser/01/01 kompcg.htm.

17 Богомаз Г., Вовк О., Кучинська О. Історія розвитку законодавства про потерпілих // Право України. - 1997. - №7. - С. 66-67. 
матеріальну й формальну ознаки злочину за Литовським статутом, відзначивши, що під охороною перебували й норми звичаєвого права. Автор публікації здійснив класифікацію злочинів на чотири групи: особливо тяжкі, тяжкі, середньої тяжкості та невеликої тяжкості зазначивши для кожної групи редакції статуту, номери розділів та артикулів, у яких певні діяння визначалися злочинними. Він підкреслив, що у другій половині XVII ст., за Гетьманщини, залишився діючим статут 1588 р., «який використовувався козацькими судами в тій частині, що мала відповідати новим реаліям життя». Є. Шаломєєв погоджується з видатним українським істориком права А. Яковлєвим, що Литовський статут був близьким правосвідомості українського народу, бо ввібрав у себе давні звичаєві українські норми та процесуальні звичаї українських копних судів ${ }^{18}$. Т. Якімець аналізує розвиток норм інституту крайньої необхідності в трьох Литовських статутах $^{19}$.

Автори низки статей торкаються цивільно-правових відносин на українських землях періоду їх входження до складу ВКЛ. Зокрема, I. Будзилович та А. Юрченко в публікації про історію оренди землі звертають увагу на те, що «Саксонське зерцало» поряд з Литовським статутом стало правовою підставою поширення на землях України відносин, які отримали назву «чиншового права», й на підставі інших досліджень розкривають їх зміст, називають суб'єктів цих відносин ${ }^{20}$. Однак, окремі їх твердження викликають подив та нерозуміння. Відзначаючи сприйняття Литвою термінології та правових норм Київської Русі й наголошуючи на обгрунтуванні в низці досліджень схожості статуту 1529 р. і «Руської правди», автори роблять досить несподіваний висновок: «Тому у центральній частині України у сфері приватно-правових відносин продовжувало діяти звичайне феодальне право, яке розвивалося на грунті «Руської правди». Натомість, та частина українських земель, що «відійшла під владу польської корони, відчула не тільки вплив феодального польського порядку, що діяв на території Польщі, але й одночасно «Руської правди», Литовського статуту та західноєвропейського права» ${ }^{21}$. Виходить, що на українських землях у складі ВКЛ впливу статуту на приватно-правові відносини не

18 Шаломєєв С.В. Розвиток поняття злочину у кримінальному праві України (X - кінець XVII ст.) // Держава і право. - К., 2002. - Вип. 16. - С. 62-64.

19 Якімець T. Розвиток інституту крайньої необхідності в українському кримінальному праві // Право України. - 2007. - № 9. - С. 114-115.

20 Будзилович I., Юрченко А. Оренда землі в Україні (історико-правовий нарис) // Право України. - 1994. - № 10. - С. 64-65.

${ }^{21}$ Там само. - C. 64. 
було, а на тих, що входили до складу Польської держави, такий вплив був. Не кажучи вже про те, що таке твердження не має історичної основи, вони є просто нелогічним. Статті притаманні й мовні огріхи. С поняття звичаєвого права, а не звичайного. Залишається незрозумілим, чому автори постійно беруть назву Руської Правди у лапки.

3 позитивного боку слід відзначити історіографічну ст.аттю, в якій аналізується історико-правова література XIX-XX ст., присвячену розвиткові норм цивільного звичаєвого права України, що регулювали земельні відносини. Зокрема, іiі автор, Б. Бачур, наголошує, що роботи Ф.І. Леонтовича та М.Ф. Владимирського-Буданова внесли величезну роль у вивчення українського звичаєвого права періоду Великого князівства Литовського і Речі Посполитої. У статті звертається увага й на те, що як у дореволюційний час, так і сьогодні «залишається недостатньо вивчене таке специфічне для України явище, як інститут чиншового права, що проіснував на українських землях майже без будь-яких змін протягом декількох століть і цілком вхідний у сферу звичаєвого права». Серед його дослідників автор статті називає таких, як С. Дибовський, I. Рудченко, В.А. Незабитовський (роботи опубліковані у 1880-х роках). Б. Бачур не погоджується 3 думкою В.І. Пічети, що в результаті аграрної реформи XVI ст.. було майже цілком зруйноване общинне землеволодіння, посилаючись на дослідження Д.Л. Похилевича. Разом $з$ тим, він вказує й на певні упущення останнього. Також автор відкидає твердження О.Ф. Кистяківського, що на території України частіше вживаною була не південно-західна (українська), а польська редакція Литовського статуту ${ }^{22}$. Добре знання історіографії Б. Бачур продемонстрував і в кандидатській дисертації. Регулюванню земельних відносин у цивільному звичаєвому праві України в XIV - першій половині XVIII ст. присвячено ïi другий розділ, у якому автор розглянув інститути чиншового права, спільної та общинної власності. Автор обстоює позицію, що волочна поміра не зруйнувала общинного землеволодіння. Ним також проаналізовано такі аспекти, як давність володіння, спосіб набуття прав на землю ${ }^{23}$.

22 Бачур Б.С. Інститут земельних відносин у звичаєвому праві України (історіографія питання) // Вісник Одеського інституту внутрішніх справ. - 2003. № 1. - С. 94, 97, 98, 102.

23 Його ж. Інститут земельних відносин у цивільному звичаєвому праві України в X - середині XIX ст. (історико-правовий аспект). Автореф. ... канд. юр. наук. 12.00.01 - теорія та історія держави і права; історія політичних і правових учень. - Х., 2004 // http://www.law1.boom.ru/diser/01/k1538-04.htm. 
O.I. Нелін проаналізував норми спадкового права, що знайшли відображення у Третьому Литовському статуті, зокрема, обмеження права заповіту, вимоги до заповіту, обмеження кола осіб, які могли засвідчувати заповіт, успадкування батьківського і материнського майна, визнання майна виморочним і перехід його до держави ${ }^{24}$.

Правове регулювання державної реєстрації речових прав на нерухоме майно, передусім на землю, стало предметом уваги О.В. Мартинюка та С.О.Слободянюка. Серед іншого, автори звертаються й до регламентації цих відносин Литовськими статутами ${ }^{25}$.

Побіжно статутів торкнувся С. Русу, розглядаючи історію розвитку деліктних зобов'язань в Україні ${ }^{26}$. Посилаючись на один з підручників, він стверджує, що козаки на своїй території не визнавали дії магдебурзького права та Литовських статутів, а правосуддя відбувалося лише у відповідності зі стародавніми звичаями. 3 цим, загалом, можна погодитися, однак варто нагадати, що на звичаєве право запорожців мали вплив і статути (вище вже говорилось про статтю I. Грозовського). М. Краснова в публікації, присвяченій законодавству про компенсацію екологічної шкоди, також згадує Литовські статути і «Уставу на волоки» 1557 p. ${ }^{27}$ Проте, на нашу думку, твердження про екологічний характер положень статутів є явною натяжкою - автор і сама зазначає: «Більшість вчених, які досліджували правові засади функціонування Київської Русі та держав, що існували на іiі теренах, однаково розглядають правові заходи охорони природних ресурсів ... передусім як об'єктів права власності». Певною мірою можна погодитися з «екологічністю» артикулу 40 «Устави», що забороняв вилов риби під час нересту та запроваджував посаду ревізора (інспектора).

А. Федущак-Паславська, аналізуючи вплив норм, принципів римського приватного права на українське законодавство від Київської Русі до початку XXI ст., відзначила, що дослідники вказують на вплив Дигестів і Кодексу Юстиніана на статут 1566 р. і особливо на статут 1588 р., а джерелом Литовських статутів є також польське та німецьке право, зокрема Швабське і Саксонське зерцала, які «формувалися під значним впливом римського права, а також давньоруське право, яке

${ }^{24}$ Нелін О.І. До питання спадкового права... - С. 50-52.

25 Мартинюк О.В., Слободянюк С.О. Еволюція правового регулювання державної реєстрації речових прав на нерухоме майно в Україні (X-XVIII ст.) // Держава і право. - К., 2007. - Вип. 36. - С. 148-149.

26 РусуC. Історія розвитку деліктних зобов'язань в Україні // Право України. - 2001. - № 2. - С. 120-121.

27 Краснова М. Історичні засади законодавства про компенсацію екологічної шкоди (з давніх часів і до кінця ХІХ ст.) // Право України. - 2007. - № 5. - С. 151. 
зазнало впливу візантійського та безпосередньо римського права». А Литовські статути своєю чергою стали одним з джерел «Прав, за якими судиться малоросійський народ» 1743 р. ${ }^{28}$

Значний інтерес українські автори виявляють до розвитку самоврядування, зокрема, його організації в містах, що отримали магдебурзьке право. П. Гураль на основі досліджень істориків і почасти опублікованих джерел аналізує волосну громаду та іï роль в системі самоврядування в період входження українських земель до складу ВКЛ. Він акцентує увагу на тому, що, на відміну, від воєводства і повіту, волость не була привнесеною ззовні структурою, а еволюціонувала 3 давньоруської доби. «У XIV-XV ст. волості підпорядковувались великокнязівському апарату влади, проте поступово переходили спочатку у тимчасове, а згодом і довічне володіння окремих князів та шляхти». Автор відзначає, що волосну громаду очолював староста, за вибори якого представники великокнязівських урядів на місцях брали заздалегідь встановлену плату. Згідно з Волосною уставою 1560 р., старосту призначала місцева адміністрація із запропонованих волостю кандидатів. Деякими волостями на північному сході Київщини керували сотники, відомі ще 3 часів Володимира Святославовича. Старости та сотники репрезентували свою волость у відносинах 3 іншими волостями, господарськими намісниками або окремими феодалами. А великий князь здійснював контроль за діяльністю волосних громад. Дослідник звертає увагу на роль віча (копи), що виконувало у волості нормотворчі, а найчастіше судові функції ${ }^{29}$. в статті помилка, обумовлена браком історичної освіти: так, П. Гураль кількість населення Кременецької волості в останній чверті XV ст. «человек полчетвертаста» трактує не як 350 , а як $200^{30}$. На наш погляд, не було жодної необхідності на початку статті давати короткий компілятивний огляд кодифікації законодавства ВКЛ (тим більше, зазначати в анотації дослідження процесу кодифікації права) $)^{31}$, оскільки далі цей матеріал ніяк не використовується.

28 Федущзак-Паславська А. До питання про рецепцію римського приватного права в Україні // Вісник Львівського університету. Серія Юридична. - Л.: Видавн. центр ЛНУ ім. Івана Франка, 2002. - Вип. 37. - С. 151, 152.

29 Гураль П. Волосна громада в період входження українських земель до Великого князівства Литовського // Там само. - С. 86-92.

30 Там само. - С. 88.

31 Там само. - C. 83-85. 
Стаття В. Кіселичника, у якій згадуються й українські міста ВКЛ ${ }^{32}$, має загальний характер і грунтується на роботах інших дослідників, сам же автор з правовими пам'ятками не працював. Значно змістовнішою $\epsilon$ публікація Е. Горян, у якій характеризуються повноваження старост, війтів, цехова організація міського населення, особливості самоврядування в містах з магдебурзьким правом ${ }^{33}$. Однак ця стаття, як і попередня, є повністю компілятивною. На шпальтах часопису «Людина і влада» історик М. Капраль здійснив порівняльний аналіз самоврядування Києва і Львова на магдебурзькому праві наприкінці XV - в першій половині XVII ст. Він відзначив, що спільним була боротьба міських громад за певні привілеї, непідлеглість місцевим урядовцям. «Перебуваючи з 1569 р. в єдиному державному законодавчому полі, українські міста відчували несприятливий політичний та економічний тиск привілейованого шляхетського стану». Поряд 3 Кам'янцемПодільським, Київ ті Львів найповніше користувалися правом самоврядування: міському урядові були підпорядковані посада війта та судова влада у місті. Дослідник вказує й причини головної відмінності слабшого рівня самоуправління Києва. Підсумовуючи, він зазначає, що «на відміну від країн Західної Свропи на українських землях, незважаючи на достатньо тривале існування та широке розповсюдження міського самоврядування на основі магдебурзького права, навіть у найбільших містах не вдалося витворити економічно потужного та політично впливового міщанства», тоді як саме таке міщанство західноєвропейських держав, «закладало підвалини нових суспільно-економічних відносин $\rangle^{34}$. На жаль, стаття не має наукового апарату, що, очевидно, обумовлено форматом даного теоретичного і громадсько-політичного журналу. Один з авторів висловив думку, що згаданий у листі великого князя литовського Олександра 1494 р., яким підтверджувалися надані раніше киянам права, лист його батька - це «Жалувальна грамота» Казимира від 2 травня 1457 р., адресована литовському, руському та жмудському духовенству, шляхті, рицарству боярам і местичам ${ }^{35}$.

Рецепції німецького права присвячена стаття В. Рубаника. В основному автор концентрується на особливостях інституту права

${ }^{32}$ Кіселичник B. Про надання українським містам у XIV-XVII ст. Магдебурзького права // Право України. - 1996. - № 9. - С. 83-84.

33 Горян $E$. Місцеві органи влади на українських землях (з часів Київської Русі до 1861 р.) // Підприємництво, господарство і право. - 2002. - № 9. - С. 101-102.

${ }^{34}$ Капраль М. Доля - спільна, труднощі - різні. Самоврядування Києва та Львова на магдебурзькому праві (кінець XV - перша половина XVII ст.): порівняльний аналіз // Людина і влада. - 2000. - №1-2. - С. 75-77.

35 Павлов А. Литовський статут... - С. 146. 
власності у пізньофеодальній системі речових права за німецьким правом на українських землях в складі Польщі, хоча інколи згадує й про землі в складі ВКЛ ${ }^{36}$. Він продемонстрував досить добру обізнаність 3 історичною та історико-правовою літературою, зокрема польською, однак обійшовся без джерел.

Слід відзначити здійснену I. Усенком публікацію в збірнику «Правова держава» двох раніше не друкованих доповідей професора С. Іваницького-Василенка, прочитаних ще 1921 р., про джерела магдебурзького права в Західній Русі та Гетьманщині. Їм передує детальна стаття I. Усенка про життєвий i науковий шлях вченого ${ }^{37}$. Відзначаючи його внесок, автор статті підкреслює, що «С.М. Іваницький-Василенко $\quad$... одним 3 перших у вітчизняній iсторіографії не зупинився на традиційному питанні: які книжки магдебурзького права діяли в Україні, а пішов далі, намагаючись 3'ясувати, чим норми, вміщені в цих книжках, відрізнялися від ïx аналогів у німецьких містах. Було закладено методологічний підхід, який, на жаль, ще й досі не знайшов гідного продовження» ${ }^{38}$. Перша доповідь пов'язана 3 практичним питанням відбору джерел магдебурзького права для публікації. Професор звернув увагу, що на українських і білоруських землях його поширення мало відмінності від поширення у німецьких землях, де старе місто (Mutterstadt) надавало виклад права новому містові (Fochterstadt) й виступало для останнього апеляційною інстанцією. Він висловив думку, що головними джерелами магдебурзького права «литовської доби» була усна його передача й твори Гроїцького і Щербича, а у Гетьманщині - оригінали останніх, а також їх переклади i переробки. Виходячи 3 цього, С. Іваницький-Василенко вважав за необхідне передусім «видати оригінальні, писані польською мовою, твори Гроїцького й Щербича» ${ }^{39}$. У другій доповіді вчений поставив за мету на основі досліджень Даргуна й Тарановського та власних спостережень визначити, наскільки Гроїцький та Щербич, викладаючи магдебурзьке право, відійшли від його джерел. С. Іваницький-Василенко встановив,

36 Рубаник В. Особливості інституту права власності в українських землях у пізньофеодальній системі речових прав за німецьким правом // Вісник Академії правових наук України. - 2001. - №4 (27). - С. 80-83.

37 Усенко I. Сергій Михайлович Іваницький-Василенко і його дослідження джерел Магдебурзького права // Правова держава: Щорічник наук. праць. - К., 2001. - Вип. 12. - С. 113-122.

${ }^{38}$ Там само. - C. 118.

39 Іваницький-Василенко С.М. Джерела Магдебургського права в Західній Русі й Гетьманщині // Правова держава. - К., 2001. - Вип. 12. - С. 123-131. 
що Гроїцький у своїх творах не давав повного і правдивого образу магдебурзького права: при перекладі статей Speculum Saxonum i Jus Municipale Magdeburgense він передавав лише основний зміст, нерідко опускаючи фрагменти статей, крім того, користувався й іншими джерелами, вставляв свої та чужі теоретичні міркування. Щербич же здійснював дослівний переклад 3 німецької на польську мову, розміщуючи фрагменти в алфавітному порядку. Підводячи підсумок, вчений відзначив, що історико-догматичне вивчення джерел магдебурзького права в Західній Русі й Гетьманщині має для історика права особливе значення: Speculum Saxonum i Jus Municipale Magdeburgense були рециповані тут разом із своїми глосами, що у багато разів перевищували обсягом самий Saxon, а глоса грунтувалася не тільки на законі, а й на римському праві - таким чином в Литовські статути й правове життя Західної Русі могли проникати норми 3 інших систем права, зокрема, з римського права ${ }^{40}$.

О. Мироненко та В. Срмолаєв звернули увагу на представницький орган ВКЛ, включаючи регулювання його діяльності положеннями Литовських статутів. Перший висловив думку, що «така протопарламентська інституція Великого князівства Литовського як Пани-Рада» була «своєрідним синтезом руських боярських рад (дум) i суто віленських княжих рад», яка до кінця XV ст. функціонувала майже винятково на підставах звичаєвого права. Пани-Рада виникла як дорадчий орган при великому князеві, але 3 часом іiі компетенція стрімко зростає: тут зосереджуються функції не лише законодавчої, а й контрольної, виконавчої та судової влади. О. Мироненко вважає, що зростанню авторитету представницького органу сприяло часте перебування великого князя, який одночасно був ще й польським королем, за межами Литви. Внаслідок полонізації у Литві починають скликати сейм, який, на думку дослідника, стає дійсно загальним (вальним) 31440 р. 3 цього часу Пани-Рада виступає у вигляді «верхньої палати», що диктує свою волю членам зборів. Дослідник відзначає, що протягом XV-XVI ст. русько-литовські сейми поступово перетворювались на представницькі установи парламентського типу, але не загальноєвропейського зразка, бо представництво зводилось лише до шляхетського стану. Варто відзначити, що О. Мироненко порівнює процес становлення представницьких установ у Литві

40 Його ж. Історико-догматичне виучування джерел Магдебургського права в Західній Русі і Гетьманщині // Там само. - С. 131-139. 
та Польщі ${ }^{41}$. Дуже коротко автор торкнувся діяльності міських представницьких установ у XIV-XVI ст. ${ }^{42}$ Так само коротко розглянуто правові засади функціонування як загальнодержавних, так і місцевих представницьких інституцій. Зокрема, О. Мироненко відзначив вплив давньоруського права i рецепцію через Польщу німецького права шляхом перекладів магдебурзьких кодексів. Пани-Рада керувалася у своїй діяльності князівськими привілеями, охоронними грамотами, земськими уставними грамотами. Особливе значення мали три редакції Литовського статуту. На жаль, О. Мироненко не аналізує, яким чином положення зазначених актів використовувались у діяльності представницьких органів. ${ }^{43}$ Суттєвим недоліком однієї із статей $є$ відсутність наукового апарату.

Така вада не притаманна для статті В. Єрмолаєва, однак на її початку знаходимо помилку, якої не гоже припускатися й школярам: «Внаслідок Кревської унії 1409 р. було сформовано союз двох держав...» (хоча далі говориться, що Ягайло уклав Кревську унію в 1385 р.). Та й українською мовою збори не «сословні», а станові ${ }^{44}$. Зазначивши, що представницькі органи Польщі та Литви формувалися за зразком Київської Русі, автор, посилаючись на інших дослідників, пише про існування при литовських князях уже в середині XIII ст. боярської ради, яка була дорадчим органом. На початку 30-х років XV ст. до неї ввійшли руські князі та бояри. «Вплив і авторитет Пани-ради, - вважає дослідник, - були зумовлені тим, що до їі складу входили вищі посадові особи держави, князі та окремі феодали за особистим запрошенням великого князя». Як і О. Мироненко, В. Єрмолаєв відзначає, що Пани-Рада була постійно діючим законодавчим, виконавчо-розпорядчим, контролюючим i судовим органом. Однак останній звертається до Литовських Статутів, аби показати закріплення правового статусу Панів-Ради та шляхетських вольностей, до Литовської метрики - говорячи про листування великого князя 3 панами радними ${ }^{45}$. Сеймам відведено менше місця. Вони охарактеризовані за монографією Максимейка «Сеймы Литовско-

41 Мироненко О. Представницькі органи Литовсько-Руської держави в контексті еволюції українського парламентаризму // Вісник Академії правових наук України. - 1997. - №2 (9). - С. 42-45; Його ж. Захист “правди” і “благодаті” за доби Київської Русі та Литовсько-Руської держави // Вісник Конституційного Суду України. - 1999. - №1 (9). - С. 73-76.

42 Мироненко О. Представницькі органи... - С. 45-46.

43 Там само. - C. 47.

44 Єрмолаєв В.М. Представницькі органи в Україні доби Литовсько-Руської держави і Речі Посполитої // Вісник Одеського інституту внутрішніх справ. 2003. - №1. - C. 111, 114.

45 Там само. - C. 111-113.

UKRAINA LITHUANICA. - K., 2009. - T. I 
Русского государства до Люблинской унии 1569 г.» та Буркулабівським літописом, хоча актових джерел про їх роботу достатньо, зокрема, й опублікованих. Аналіз сеймової реформи 1565-1566 pр. здійснений автором на основі артикулів Другого Литовського Статуту, у яких закріплювались повноваження сеймів і повітових сеймиків, організація їх роботи ${ }^{46}$.

Українські автори також досліджують становлення та функціонування різних судів і судочинство. В. Сердюк присвячує свою статтю найвищому судовому органу в українських землях у XIV середині XVII ст. (хоча, на нашу думку, назва статті значно вужче iï змісту). Автор відзначає, що судоустрій та судочинство на українських землях ВКЛ пройшли три етапи змін. Перший етап охоплює час від «захоплення території руських князівств у середині XIV ст. до укладення Кревської унії між Литвою і Польщею в 1385 p.» й характеризується подальшим пануванням місцевого права у всіх галузях, незначними змінами в організації та компетенції судових установ i утворенням суду великого князя над підлеглими йому князями. На другому етапі (з 1385 р. до ухвалення Другого Литовського статуту в 1566 р.) відбувається інтенсивне проникнення на територію сучасної України західноєвропейського та польського права, а також проводяться суттєві зміни в судоустрої після Бєльського сейму 1564 р., пов'язані «з позбавленнями магнатів і шляхти права судової юрисдикції та ст.воренням великим князем нової системи державних судів». В. Сердюк коротко характеризує компетенцію господарського, комісарського, межового, асесорського, маршалкового судів, суду ПанівРади, доменіальних, міських, копних, церковних судів. Третій етап охоплює період від 1566 р. до кінця XVIII ст., коли, за твердженням автора, відбувся остаточний розпад Речі Посполитої. Для цього часу дається характеристика земського, гродського (замкового), підкоморського судів, що функціонували у повітах. Якщо попередня частина статті написана на основі інших досліджень, то тут В. Сердюк звертається до опублікованих і архівних джере ${ }^{47}$ (однак, йому залишилася невідомою цікава стаття О. Сокальської, яку ми розглянемо нижче).

Про судочинство ВКЛ писав і Л. Коваленко ${ }^{48}$. Однак і ця частина вже згадуваної статті нічого нового не містить - вище вже говорилось про іiі компілятивний характер.

46 Там само. - С. 114-115.

47 Сердюк $B$. Найвищий судовий орган в українських землях за часів їх перебування у складі Литви, Польщі та Речі Посполитої (XIV - середина XVII ст.) // Право України. - 2006. - №3. - С. 124-126.

48 Коваленко Л. Право Великого князівства Литовського... - С. 94-95. 
М. Прийдак присвячує свою статтю управлінню судовими органами України від часів словенів і антів до 1963 р. Періодові входження українських земель до складу ВКЛ у ній відведено лише три коротких абзаци загального характеру ${ }^{49}$.

На становлення підкоморського суду в Україні в другій половині XVI ст. звернула увагу О. Сокальська. Зокрема, автор підкреслила вимоги шляхти щодо реформування судової системи, що знайшли відображення у Другому Литовському статуті, право шляхтичів висувати кандидатів на посаду підкоморія, закріплене у Третьому статуті. Останнє викликало й зміну тексту присяги при вступі підкоморія на посаду. Автор аналізує причини появи посади коморника та його функції. На іï думку, ця посада в підкоморських судах на українських землях з'явилась у 80x роках XVI ст. Центральне місце статті посідає аналіз повноважень суду, законодавче регулювання та практика розгляду справ і ведення судових книг. Також розглянуто судові витрати та оплату роботи членів підкоморського суду. Дослідниця підкреслила, що статут 1588 р. значно детальніше регламентував діяльність даної судової установи, ніж попередній. Вона відзначила, що на Правобережній Україні підкоморські суди діяли до 30-х років XIX ст., а в Гетьманщині їх передбачалося утворити царським указом від 8 травня 1763 р. «Їх запровадження було одним із етапів судової реформи 1763 р., яка відновлювала повітові гродські, земські та підкоморські суди як установи, що найбільше відповідали інтересам старшинської верхівки, яка вбачала у них можливість політичної незалежності, громадянської свободи, широких прав та привілеїв...» - підсумовує автор свої студії. Слід наголосити, що висновки О. Сокальська здійснила передусім на основі аналізу опублікованих та архівних джерел ${ }^{50}$.

С.Г. Ковальова, наголосивши, що ряд аспектів діяльності третейських судів на українських землях лишилися поза увагою дослідників, зокрема, Ф. Леонтовича, вирішила на основі судових актів уточнити і доповнити відомості про них. Вона відзначає, що на початку діяльності третейські суди не були постійною установою й призначалися для кожної конкретної справи після подання заяви до великокнязівської канцелярії. А до кінця XV ст. судді вже не призначалися, а обиралися сторонами. Відзначивши, що рішення третейських судів були такими ж обов'язковими, як і державних,

49 Прийдак M. Управління судовими органами в Україні (історико-політичний та правовий аспект) // Право України. - 1993. - №7-8. - С. 29.

${ }^{50}$ Сокальська O.B. Становлення підкоморського суду в Україні (друга половина XVI ст.) // Держава і право. - К., 2002. - Вип. 15. - С. 78-85.

UKRAINA LITHUANICA. - K., 2009. - T. I. 
автор посилається на положення Другого Литовського статуту про забезпечення вироку третейського суду, перенесення справи до земського суду за відсутності згоди і Третього статуту - про визначення земського суду апеляційною інстанцією для третейських судів ${ }^{51}$.

Друга частина статті С.Г. Ковальової присвячена полюбовним (мировим) судам. Вони відрізнялися від третейських тим, що сторони, які вдавалися до мирового суду, обирали мирових суддів, не повідомляючи про це державний суд і до офіційного порушення справи у державному суді. Рішення мирових судів, що розглядали переважно цивільні та дрібні кримінальні справи, мали таку ж юридичну силу, як і рішення третейських судів ${ }^{52}$.

Ще одна стаття С.Г. Ковальової, виконана на основі опублікованих джерел, присвячена інституту свідків у судовому процесі. Автор звернула увагу на роль свідків у досудових процесуальних діях, але основне місце відведено їх участі в суді. Показано вимоги до свідків й обмеження щодо участі особи в процесі як свідка, відбір свідків, їх роль і значення у вирішенні справ, передусім, спорів про землю ${ }^{53}$.

Матеріали вказаних статей знайшли відображення в одному 3 розділів кандидатської дисертації С.Г. Ковальової ${ }^{54}$.

Розвиток нотаріату на українських землях в складі ВКЛ розглянула Л. Ясінська. Відзначивши, що звичай внесення до актових книг правочинів сформувався, принаймні, в кінці XV - на початку XVI ст., вона підкреслила, що Перший Литовський статут закріпив обов'язкову письмову форму позики на загальну суму понад 10 кіп грошей, угод про землю, переходу права власності на маєтки. Автор також детально проаналізувала, хто здійснював актові записи, у які види актових книг вони вносилися, значення інститутів «запису» (урядово засвідченої копії або заяви сторони, що вписувалася в урядову книгу) і «випису» (урядово засвідченої копії, яку видавали на руки стороні і яка мала силу оригіналу ${ }^{55}$.

${ }^{51}$ Ковальова С.Г. Третейські суди на українських землях Великого князівства Литовського // Держава і право. - К., 2001. - Вип. 13. - С. 68-70.

52 Там само. - С. 70-71.

53 Ковальова С.Г. Інститут свідків у судовому процесі на українських землях Великого князівства Литовського // Митна справа. - 2003. - №6. - С. 84-87.

54 Ï̈ ж. Еволюція судової системи і судочинства на українських землях Великого князівства Литовського. Автореф. ... канд. юр. наук. 12.00.01 - теорія та історія держави і права; історія політичних і правових учень. - Одеса, 2004 // http://www.law1.boom.ru/ diser/01/k2920-04.htm.

55 Ясінська Л. Розвиток нотаріальної діяльності в Україні XIV-XVII ст. // Вісник Львівського університету. Серія юридична. -Л.: Видавн. центр ЛНУ ім. Івана Франка, 2006. - Вип. 43. - С. 105-109. 
Розглядаючи правову культуру українського суспільства в період входження українських земель до складу ВКЛ, А. Скуратівський основну увагу акцентує на Литовських статутах. Він підкреслює, що, 3 одного боку, статути були визначними джерелами права феодальної Європи, які «прагнули охопити правовим регулюванням усі сфери життя суспільства, поглиблювали права і свободи певної соціальної верстви суспільства, зокрема шляхти». 3 іншого ж боку, зазначає автор, статути негативно вплинули на формування правової культури, бо в них «прослідковується тенденція на обмеження прав і свобод населення, насамперед основної його соціальної верстви - селянства, до повного його закріпачення». Крім того, статути поступово відмежовуються від гуманістичних засад давньоруського права: штраф як основний вид покарання відіграє все меншу роль, а домінуючою стає система норм, спрямованих на залякування, фізичні покарання, позбавлення волі тощо. Звідси А. Скуратівський робить висновок, що все це «звужувало можливості усвідомленого сприйняття населенням правових норм формування правової культури суспільства ${ }^{56}$. Не кажучи вже про те, що процитоване положення є досить складною і не зовсім зрозумілою мовною конструкцією, варто відзначити, що воно суттєво розходиться iз згадуваними вище твердженнями І. Грозовського та В. Щербака про відчутний вплив литовського права на правосвідомість українського населення ${ }^{57}$.

Підсумовуючи викладене, слід відзначити, що з початку 90-х років минулого століття питання зародження та розвитку державно-правових інститутів, які мали місце на українських землях у період їх входження до Великого князівства Литовського, привертають дедалі більшу увагу вітчизняних юристів. Передусім це стосується таких аспектів як вплив норм давньоруського права на Литовські статути та вплив останніх на розвиток українського права. За галузями найбільша кількість публікацій присвячена кримінальному праву. Об'єктом дослідження цивілістів стали право власності, земельна власність та спадкове право. Значний інтерес привертає організація та функціонування як загальнодержавних, так i місцевих представницьких органів, судових установ.

Дослідження українських правників, як і істориків, переважно є регіональними: їх автори рідко звертаються до аналізу певного явища

56 Скуратівський A. Правова культура українського суспільства: витоки, становлення та основні етапи розвитку // Вісник Української Академії державного управління при Презедентові України. - 2001. - №3. - С. 297-298.

57 Грозовський I. Феномен козацького права. - С. 125; Щербак В. Витоки та становлення козацького права. - С. 121.

UKRAINA LITHUANICA. - K., 2009. - T. I. 
чи державно-правового інституту в межах всього ВКЛ, обмежуючись українськими землями в його складі.

Не можна не відзначити, що рівень історико-правових публікацій залишає бажати кращого. Чимало робіт $є$ компілятивними. Залучення історичних джерел залишається спорадичним, хоча слід зауважити, що в цьому аспекті є суттєвий поступ - частина дослідників звертається як до опублікованих, так і до архівних джерел. Загалом же можна повторити побажання, висловлене автором даної статті ще у 2000 р.: «Джерельна база навіть кращих самостійних досліджень може бути істотно розширена. Для цього потрібно, щоб юристи ... ретельніше знайомилися 3 джерелознавчими, археографічними, історіографічними дослідженнями, історичними роботами, які нерідко містять аспекти розвитку держави і права, архівними путівниками...> ${ }^{58}$

Як позитивне явище можна охарактеризувати появу історіографічних досліджень. Однак, їх автори акцентують увагу переважно на відомих виданнях кінця ХІХ - середини XX ст.. А от публікації сучасних істориків (а інколи навіть і правників) не потрапляють до їх поля зору. Проте істориками досить активно розробляються окремі правові аспекти: джерела та процес формування Литовських статутів ${ }^{59}$, правове регулювання землеволодіння ${ }^{60}$, становлення Сейму ВКЛ ${ }^{61}$, територіальна громада, міста та органи місцевого самоврядування ${ }^{62}$,

58 Дячок О.О. Джерельна база публікацій $з$ історико-правової тематики на шпальтах часопису “Право України” // Вісник Дніпропетровського університету. Історія та археологія. - Дніпропетровськ, 2000. - Вип. 8. - С. 159.

59 Ващук Д. Вплив обласних привілеїв Київщини та Волині на формування Першого Литовського Статуту // Україна в Центрально-Східній Європі. - К., 2004. Вип. 4. - С. 177-194; Його ж. Непорушність “старини”: державна політика Великого князівства Литовського чи історіографічна традиція кінця XIX - першої третини ХХ ст. // Україна в Центрально-Східній Європі. - К., 2006. - Вип. 6. - С. 423-438.

60 Блануца $A$. Правові основи шляхетського землеволодіння за Другим Литовським Статутом 1566 р. // Україна в Центрально-Східній Європі. - К., 2003. Вип. 3. - С. 129-138; Його ж. Матеріали до реєстру земельних контрактів волинської шляхти (друга половина XVI ст.). - К., 2005; Його ж. Земельні володіння Волинської шляхти в другій половині XVI ст. - К., 2007. - С. 72-107.

${ }^{61}$ Григор'єв В. Витоки станово-представницької системи влади та процес iii запровадження на українських землях Великого князівства Литовського (XVXVI ст.) // Український історичний збірник. 2002. - К., 2003. - Вип. 5. - С. 55-70.

62 Гурбик А. Типологія територіальної громади в Україні XIV-XVIII ст. // Україна в Центрально-Східній Європі. - К., 2000. - Вип. 1. - С. 75-96; Білоус Н. Київський магістрат XVI - першої половини XVII ст.: організація та структура влади // Соціум. Альманах соціальної історії. - К., 2003. - Вип. 2. - С. 23-39; Ï̈ ж. Функції та основні напрями діяльності Київського магістрату в XVI - першій половині XVII ст. // Український історичний журнал. - 2005. - №5. - С. 4-17; Заящь A. 
функціонування судів і судочинство ${ }^{63}$, розвиток інституту адвокатури ${ }^{64}$, інститут офіційних свідків ${ }^{65}$, витоки та становлення козацького права ${ }^{66}$, правове регулювання торгових відносин ${ }^{67}$. Суттєвим недоліком історико-правових публікацій є незнання більшістю авторів доробку іноземних істориків та істориків права.

Однак є підстави сподіватися, що в перспективі зростатиме як кількість досліджень державно-правових інститутів ВКЛ і українських земель у його складі, виконаних вітчизняними правознавцями, так i ïx якість.

Урбанізаційний процес на Волині в XVI - першій половині XVII століття. - Л., 2003. - C. 91-105, 137-146.

${ }^{63}$ Крупка О. Земська судова номенклатура Правобережної України у другій половині XVI - першій половині XVII століть // Україна в Центрально-Східній Європі. - К., 2000. - Вип. 1. - С. 173-181; Поліщук В.В. Луцький замковий уряд в адміністративній системі Великого князівства Литовського до реформи 15641566 рр. // Українській історичний журнал. - 2003. - № 2. - С. 3-14; 2005. - № 1. С. 108-125; Вилимас Д. Элита и повседневность земских судов Упитского повета в 1566-1588 гг. (по материалам упитских земских судов) // Соціум. Альманах соціальної історії. - К., 2005. - Вип. 5. - С. 41-50; Ващук Д. Судова діяльність "старости" на Волині та "воєводи" на Київщині в кінці XV - першій третині XVI століття // Україна в Центрально-Східній Європі. - К., 2005. - Вип. 5. - С. 157-172; Його ж. Порівняльний аналіз привілеїв литовським євреям та уставних земських грамот Київщини та Волині (друга половина XV - перша третина XVI ст.) // Український історичний збірник. 2002. - К, 2003. - Вип. 5. - С. 43-54; Його ж. Судовий процес та його функціонування в Київській землі в другій половині XV - першій третині XVI ст. (аналіз статей уставних земських грамот) // Український історичний збірник. 2004. - К, 2004. - Вип. 7. C. 69-94; Його ж. Загальні принципи судочинства Великого князівства Литовського в другій половині XV - першій третині XVI ст. (на прикладі Київської землі) // Наукові праці Кам'янець-Подільського державного університету: Історичні науки. - Кам'янецьПодільський: Оіюм, 2006. - Т. 16. На пошану професора А.О. Копилова. - С. 20-30.

${ }^{64}$ Старченко Н. Умоцовані - прокуратори - приятелі. Хто вони? (становлення інституту адвокатури на Волині в кінці XVI ст.) // Соціум. Альманах соціальної історії. - К., 2002. - Вип. 1. - С. 111-144.

${ }^{65}$ Полішук В. Врядове вижівство в структурі публічно-правових процедур (на матеріалах луцьких замкових книг 1558 - 1657 рр.) // Соціум. Альманах соціальної історії. - К., 2002. - Вип. 1. - С. 79-109.

${ }^{66}$ Щербак В. Витоки та становлення козацького права. - С. 119-127.

67 Берковський $B$. Деякі аспекти розвитку системи правового регулювання торгових відносин на Волині у XVI - першій половині XVII ст.: митне і торгове право // Український історичний збірник. 2002. - К., 2003. - Вип. 5. - С. 78-92.

UKRAINA LITHUUNICA. - K., 2009. - T. I. 


\section{Diachock Oleg}

\section{The Law of the Grand Duchy of Lithuania and Ukrainian lands inside} one on the pages of Ukrainian juridical editions (1991-2007)

From the beginning of 1990ies the problems of the state-legal institutions genesis and development, which functioned on the Ukrainian lands which were part of the Grand Duchy of Lithuania, attract more and more attention of the native lawyers. First of all this concerns such aspects as impact of the oldrus' law' standards upon Lithuanian Statutes and the impact of the latter upon Ukrainian law development (D. Lubchenko, O. Korostashov). The majority of publications are dedicated to the criminal law (S. Kudin, E. Shalomeyev). The property, landed property and the inheritance law become an object of research of the scientists who specialized in civil law (O. Nelin). The organization and functioning of both the state and the local representative bodies (O. Myronenko, V. Ermolayev), judicial settings (V. Serduk, O. Sokal's'ka, S. Kovaliova) arouse great interest.

The level of the historical-law publications leaves much to be desired; in particular, the expansion of the source and historiography base is necessary. At the same time, we can observe some positive tendencies in this direction. 